\title{
Relationship Between Parasitic Infections in Diabetic Patients and the Importance of Raman Spectroscopy in Determining Parasites at Molecular Level
}

\author{
Berna Hamamci*, Gunes Acikgoz \\ Hatay Vocational School of Health Services, Hatay Mustafa Kemal University, Hatay, Turkey \\ Email address: \\ uzmberna@hotmail.com (B. Hamamci),gunesboraacikgoz@gmail.com (G. Acikgoz) \\ ${ }^{*}$ Corresponding author
}

\section{To cite this article:}

Berna Hamamci, Gunes Acikgoz. Relationship Between Parasitic Infections in Diabetic Patients and the Importance of Raman Spectroscopy in Determining Parasites at Molecular Level. International Journal of Immunology. Special Issue: Parasitology.

Vol. 7, No. 4, 2019, pp. 41-46. doi: 10.11648/j.iji.20190704.12

Received: December 3, 2019; Accepted: December 16, 2019; Published: December 25, 2019

\begin{abstract}
Diabetes mellitus (DM) is a metabolic disorder of protein, carbohydrate and fat. Insulin secretion, insulin action, or both cause to diabetes mellitus. According to the World Health Organization, the number of diabetic patients in the world is around 200 million and it is stated that this number will reach 300 million in 2025. Parasitic diseases are widespread all over the world and are a major public health problem, especially in underdeveloped or developing countries. It ranks first among the diseases that should be controlled by the World Health Organization. Among the factors causing parasitic diseases include protozoa, helminths and arthropods. In certain geographical areas where parasitic infections are common, many autoimmune diseases such as asthma, rheumatoid arthritis (RA), type1 diabetes (T1DM), multiple sclerosis (MS), and inflammatory bowel diseases (IBD) are reported to have a lower incidence. The relationship between helminth infections on the onset and development of T1DM, one of the multigenetic diseases affected by environmental factors, is remarkable. It is not clear how helminth infections prevent T1DM development. In diabetic patients, it is known that there is a decrease in immune system functions, especially cellular immunity, and in these patients CD8 and CD16 values for suppressor T cells and NK cells are decreased compared to normal individuals. Therefore, it does not prevent the development of diabetes and can be seen more in patients with diabetes. Raman Spectroscopy (RS) is a vibrational technique due to inelastic scattering that occurs during the interaction of monochromatic laser beams with molecules. It is preferred in biomedical examinations because RS does not damage the sample and can be obtained quickly by non-invasive method. DM and different parasitic diseases can be determined by analyzing the spectra obtained in RS examinations. The obtained Raman spectra of different molecular systems are different and each system has its own fingerprint.
\end{abstract}

Keywords: Parasitic Infections, Diabetes Mellitus, Raman Spectroscopy

\section{Introduction}

\subsection{Diabetes Mellitus}

Diabetes mellitus (DM) is a metabolic disorder of protein, carbohydrate and fat. Insulin secretion, insulin action, or both cause to diabetes mellitus [1]. Insulin is made in beta cells in the islets of Langerhans in the pancreas. The secretion of insulin is controlled by nutrients, hormones and the autonomic nervous system. The main target tissues for insulin are muscle, liver and adipose tissue. Insulin increases glucose uptake, glycogen storage, amino acid uptake and protein synthesis in muscle tissue. In the liver, insulin increases glycogen synthesis and suppresses glycogen degradation. It increases triglyceride synthesis in adipose tissue. Diabetes mellitus is divided into Type 1 and Type 2 depending on the etiopathological features [2-5]. Different pathogenic mechanisms are responsible for the emergence of diabetes. The primary event in the development of Type 1 diabetes is the autoimmune mechanism. In addition, the formation of insulin deficiency as a result of the destruction of beta cells for an unknown reason causes Type 1 diabetes. The onset of Type $1 \mathrm{DM}$ is mostly seen in childhood and is 
characterized by severe insulinopenia. Patients with type $1 \mathrm{DM}$ need to take insulin from outside to survive and prevent ketosis [2-5]

Type 2 DM (non-insulin dependent DM) is the most common form of diabetes Type $2 \mathrm{DM}$ is a decrease in insulin effect due to impaired insulin secretion due to beta cell insufficiency and insulin resistance in target tissues. It is usually seen in adults, obese and inactive individuals, but can occur at any age.

The prevalence and incidence of diabetes mellitus varies according to geographic regions, ethnic groups, socioeconomic status, genetic and environmental factors [6]. DM is reported to occur in approximately $3-5 \%$ of Western societies. It has been reported that the total prevalence in the USA is $7.8 \%$ and the prevalence increases by $38 \%$ [7]. In the diabetes screening performed by the Turkish Diabetes Epidemiology Working Group (TURDEP) has been concluded that the prevalence was $7.2 \%$ in adults and $6.7 \%$ in impaired glucose tolerance. Both disorders are reported to be higher in females than in males and in urban residents more than to living in rural areas [8].

The most common Type $1 \mathrm{DM}$ in childhood and adolescence accounts for $20-25 \%$ of all diabetic patients. Type $1 \mathrm{DM}$ is a disease that occurs mostly in autumn and winter months, but it can be seen in all seasons in small age groups. The prevalence of diabetes is rapidly increasing in all developed and developing societies due to the rapid change in lifestyle [9] According to the World Health Organization, the number of diabetic patients in the world is around 200 million and it is stated that this number will reach 300 million in 2025 [10]. Four of the molecular causes of insulin resistance are noteworthy. These molecules are tumor necrosis factor- $\alpha$ (TNF- $\alpha$ ), interleukin-6 (IL-6), membrane glycoprotein plasma cell antigen-1 (PC-1) and leptin [11].

\subsection{Parasitic Infections}

Parasitic diseases are widespread all over the world and are a major public health problem, especially in underdeveloped or developing countries. It ranks first among the diseases that should be controlled by the World Health Organization [12]. Among the factors causing parasitic diseases include protozoa, helminths and arthropods. The parasites have complex life cycles and spend some or all of their lives in humans or animals, and some in intermediate hosts.

Parasites invade the host through the skin or digestive tract. There is a mutual and very close relationship between the parasite host and they constantly affect each other. Their forms, structure organelles and secreted enzymes have an antigenic effect on the host, until parasites leave the host. The host produces a different type of immune response to parasitic infections. Cellular, humoral or both types of immune responses occur in parasitic infections. The effect of the cellular immune response is realized by the recognition of antigens on the surface of sensitive $\mathrm{T}$ lymphocytes. The effect of humoral immune response is realized by antibodies in the class of specific immunoglobulins against the receptors and exotoxins of the parasite [13]. T cells, natural killer cells and cytokines are involved in cellular immunity [12]. The prevalence of parasitic diseases in the world varies depending on local feeding habits, socio-economic level, personal hygiene and environmental factors [14].

The so-called 'Hygiene Hypothesis' was first put forward by David Strachan (Strachan DP, 1989) in 1989, and this hypothesis was confirmed by different studies. [15-17]. A fact demonstrating the importance of parasites has been put forward in the hygiene hypothesis. According to this hypothesis increase of immune disorders such as diabetes and autoimmune diseases is suggested to occur due to cleaner living conditions (immunity to parasites). It is a natural consequence of this hypothesis that exposure to some parasites and microbes can prevent such diseases [18].

In some cases, parasites may alter the immune system with improved characteristics to avoid the host immune management and disrupt the effective host response. In certain geographical areas where parasitic infections are common, many autoimmune diseases such as asthma, rheumatoid arthritis (RA), type1 diabetes (T1DM), multiple sclerosis (MS), and inflammatory bowel diseases (IBD) are reported to have a lower incidence [18-21].

\subsection{Raman Spectroscopy}

Raman Spectroscopy (RS) is a vibrational technique due to inelastic scattering that occurs during the interaction of monochromatic laser beams with molecules. The wavelength used in RS is different from the wavelength of the absorption beam obtained from the sample examined [22]. Therefore, Raman spectroscopy has become increasingly popular in all sciences especially novel biomedical applications over the last decade [23].

RS can provide information about changes in metabolism of metabolic disorders and the composition of tissue at the molecular level. RS is used in the determination of the presence of organic and inorganic compounds of biological fluids, chemical compositions of human tissues and chemical measurements of blood metabolites for the quantitative analysis of clinical diagnosis and biological samples and many other studies. Therefore, it provides reliable information for determining both chemical changes in tissues and changes in metabolism [24, 25].

It is preferred in biomedical examinations because RS does not damage the sample and can be obtained quickly by noninvasive method. DM and different parasitic diseases can be determined by analyzing the spectra obtained in RS examinations [26]. The obtained Raman spectra of different molecular systems are different and each system has its own fingerprint. Molecules can be identified with the fingerprint [27].

\section{Comprehensiveness}

\subsection{Helminth Infections and Its Relationship with Diabetic Patients}

The distribution of helminthes is affected by geographical 
conditions, climate, flora, fauna, and population density, dressing and eating habits of people [12]. In the development of helminth infections in humans, host parasite relationship and consequently human defense mechanism is important. TGF- $\alpha$, IL-4, IL-10 in the host are caused the production of cytokines weakens the immune defense of the host. It forms the $\mathrm{T}$ cell response to granulomas and fibrosis that occur in many helminth infections. Eosinophilia, IL-4, IL-5, IL-13 and IgE formation are potent inducers of Th-2 [28]. Interferon $\gamma$ (IFN- $\gamma$ ) (primary activator of mononuclear phagocytes) is a cytokine that regulates immune-mediated inflammation. It activates inflammatory leukocytes by antigen-stimulated $\mathrm{CD} 4^{+}$and $\mathrm{CD} 8^{+} \mathrm{T}$ lymphocytes. Although acquired immunity is difficult in helminth infections in humans, IL-12 release due to IFN- $\gamma$ production, which occurs 6-8 days after the first infection, is important for protective effect. It also increases IgE production [13]. In diabetic patients, immune system functions, particularly cellular immunity are reduced. In these patients, CD8+, CD16+ which is the determinant of suppressor T cells and NK cells is decreased according to healthy people [14].

It has been reported that the incidence of T1DM (Type 1 Diabetes mellitus) has increased significantly in western societies in recent years. The relationship between helminth infections on the onset and development of T1DM, one of the multigenetic diseases affected by environmental factors, is remarkable [18]. It is not clear how helminth infections prevent T1DM development. But there is an inverse relationship between T1DM and filaryosis and soil-borne helminth infections; furthermore, it has been disclosed that parasites and their products spontaneously reduce T1DM development and inhibits beta-cell infiltration in mice. These findings increase the likelihood as a protective factor against T1DM in humans of helminth infections. Helminthes are excellent agents that induce polarized Th-2 type response. Some molecules need to modulate dendritic cells to develop a strong Th-2 response [29]. In non-obese (NOD) mice, insulin degradation is associated with IFN- $\gamma$ production. IFN$\gamma$ production is inhibited by IL-4 [30]. IL- $^{+}$is the most important stimulator for IgE production and development of Th-2 response from naive $\mathrm{CD}^{+}$helper $\mathrm{T}$ cells. The Th-2 response protects the host against the pathological effects of excessive inflammation caused by Th-1 cells. As a result, NOD mice with helminth infection alter Th-1-type response to Th-2 type response and inhibit T1DM development [21, 28].

Helminthes cause the production of cytokines such as IL10 or Transforming Growth Factor-Beta (TGF- $\beta$ ) in the host [30]. Th1 cytokines (IFN- $\gamma$, lenfotoksin and TNF) cause the initiation and progression of T1DM, Th-2 cytokines (IL-4, 6, 10) hinders this process [31]. In some patients, Th- 2 cells and their cytokines accelerate the destruction of $\beta$ cells (i.e. in local production of IL-10) [31].

$\mathrm{CD}^{+}, \mathrm{CD} 25^{+} \mathrm{T}$ cells are called "Regulatory $\mathrm{T}$ cells (Treg)". Regulatory cells $\left(\mathrm{CD} 4^{+}, \mathrm{CD} 25^{+}\right.$and Foxp $\left.3^{+}\right)$develop from the thymus. It inhibits autoimmune diseases by suppressing the immune response against antigens developing in the body. Furthermore, Treg cells produce IL10 and secrete TGF- $\beta$ [32]. CD $4^{+}, \mathrm{CD} 25^{+}$Treg cells are induced during helminth infections. Treg cells that inhibit the development of autoimmune diseases have a protective role in T1DM [32, 33]. Recent studies have thought that there is no decrease in the number of Foxp $3{ }^{+}$Treg in NOD mice and that Treg cells transferred to NOD mice block the development of diabetes [34].

Invariant Natural Killer T cells (INKT), such as Treg cells, are reported to be associated with T1DM [21]. INKT cells regulate the host's immune response after parasite infection [21]. IL-4 and IFN- $\gamma$ formation after $S$. mansoni infections are shown as an example. Increased INKT cells against $S$. mansoni eggs and adults have been reported to inhibit the development of T1DM in NOD mice [35].

Recent studies have increased the predominance of IFN- $\gamma$ in relation to the Th-1 type response of macrophages in many microorganisms. It also plays an important role in Th-2 type inflammatory response. These macrophages are called alternative activated macrophages [36]. Alternative activated macrophages by activation of Th- 2 cytokines such as IL-4 and IL-13 are mechanisms involved in the formation of immune response in allergy and helminth infections. The depletion of macrophage (MФs) inhibitors in NOD mice leads to the development of T1D [36].

It has been reported that the increase in T1DM in children under 14 years of age in developed countries is not only due to genetic factors [37]. It is suggested that there is an inverse relationship between poverty and T1D in underdeveloped and developing countries. The high prevalence of infection due to lack of sanitation is thought to prevent the development of autoimmune diabetes. The role of clean water in diseases such as T1DM is an example.

The relationship between $S$. mansoni and T1DM is one of the most widely studied trematodes [18]. Schistosomiasis is the oldest and biggest public health problem faced by people in the world today, causing economic losses and lasting 2530 years in humans [38]. This disease caused by Schistosoma species infects approximately 200 million people worldwide [39]. In most human cases, the causative agent is $S$. mansoni, S. japonicum and S. haematobium. S. mansoni is observed in African countries, Saudi Arabia and almost all South American countries. The parasite most often settles in the large intestine veins and lays eggs in the intestinal cavities. Parasite eggs with feces of infected persons mix into fresh waters. In the natural immune response, dendritic cells, macrophages and NKT cell modifications occur with radical changes in phenotype and cytokine secretion [36]. In the humoral immune response to $S$. mansoni, anti-schistosoma IgE antibodies, degranulation (mast cell) and eosinophil counts are increased. Here, the Th-2 response with the most important cytokines (IL-4, IL-5 and IL-3) plays a role. In the cellular immune response the Th-1 response is formed with IFN- $\gamma$ secretion [13]. The onset of the immune response to the eggs occurs through a mechanism resulting from the coexistence of Th-1, Th-2 responses. As time progresses, the entire inflammatory response regresses and granuloma 
formation occurs only due to Th-2 response. The formation of Th- 2 response and IL-10 caused by this immune response prevents the formation of protective Th- 1 immune response that causes death [13].

Experimental studies have reported that helminthes are associated with protection against many autoimmune diseases such as inflammatory bowel diseases and diabetes $[21,28,40]$. In addition, it has been explained that helminth infections may alter the immune response in allergic reactions [13].

According to studies on Trichinella spiralis and Heligmosomoides polygyrus gastrointestinal helminth infections, there was an association between diabetes development and immunology in NOD mice. These mechanisms have been reported to be different for each parasite. T. spiralis and $H$. polygyrus found that a Th-2 response occurred by increasing IL-4 and IgE levels. T1 diabetes is caused by activation of the Th- 1 pathway. Th-2 response has been shown to be induced by protection from the effects of Th-1 due to beta cell destruction in T. spiralis and $H$. polygyrus infections [28].

In addition, helminth infections provide diabetes protection by disrupting the pathways leading to beta cell destruction and thereby inhibiting autoimmune diabetes. Hygiene hypothesis the increase in autoimmune diseases such as diabetes in the world as result of reduced exposure to infectious agents. In animal models, it is emphasized that diabetes can be prevented by infectious agents such as helminths, bacteria and viruses.

\subsection{Protozoon Infections and Diabetes}

Protozoan infections cause opportunistic infections in immunosuppressed patients. Macrophages are an effective immune response to extracellular parasites. For intracellular parasites, NK cells and activated macrophages play an important role in the innate immune response. In intracellular pathogens (Leishmania spp, T. cruzi and T. gondii) Th-1 response occurs by $\mathrm{T}$ cell differentiation by producing IL-12 and IFN- $\gamma$.

Toxoplasmosis is a systemic disease caused by Toxoplasma gondii, the obligatory intracellular parasite of all mammals and birds [12]. Toxoplasmosis, a latent in healthy individuals, is a life-threatening disease in people with pregnancy and immunodeficiency [12]. T. gondii infection is reported to be quite common in patients with diabetes the course of infection is prolonged in such patients [41]. Hökelek et al. [42], they found toxoplasma seropositivity IgG in $41(73.2 \%)$ and IgM in $1(1.8 \%)$, of 56 patients with Type2 DM. Korkmaz et al. [14], they have determined toxoplasma IgG seropositivity in $30(40.5 \%)$ of 74 patients diagnosed with diabetes mellitus. In another study, they have found IgG seropositivity in $56.62 \%$ of 85 Type $1 \mathrm{DM}$ patients [41]. The host immune response to $T$. gondii is mainly mediated by cellular immunity. T cells, NK cells and cytokines play a role in cellular immunity. The most important cytokines are IFN$\gamma$, TNF- $\alpha$, interleukin-2 (IL-2), IL-6, IL-7, IL-10, IL-12 and IL-15 [13].
In different clinical of Toxoplasmosis, one of the Th- 1 and Th- 2 cytokines is said to be dominant. Th- 1 response occurs in people with immune system intact ocular toxoplasmosis. Of active chronic toxoplasmosis such as congenital toxoplasmosis, toxoplasma encephalitis and lymphadenopathy have been observed to come to the fore in the Th-2 response [43].

$\mathrm{CD}^{+}$and $\mathrm{CD}^{+} \mathrm{T}$ lymphocytes play an important role in the $T$. gondii resistance of the host. Cytokines secreted from $\mathrm{CD}^{+} \mathrm{T}$ lymphocytes help to develop resistance at the beginning of infection. In experimental studies, it is stated that toxoplasmosis mortality increases as a result of decrease in $\mathrm{CD}^{+} \mathrm{T}$ lymphocyte subgroups [13]. It was determined that the reactivation of $\mathrm{CD}^{+} \mathrm{T}$ lymphocytes was inhibited during infection in immunocompromised animals. During symptomatic toxoplasmosis, while $\mathrm{CD}^{+} \mathrm{T}$ lymphocytes, NK cells and monocyte count increased, there was no change in $\mathrm{CD}^{+} \mathrm{T}$ lymphocytes [13]. It is known that there is a decrease in immune system functions, particularly cellular immunity, in patients with diabetes. In these patients, $\mathrm{CD} 8^{+}$and $\mathrm{CD} 16^{+}$ values, which are determinants for suppressor $\mathrm{T}$ cells and $\mathrm{NK}$ cells, have decreased compared to normal people. Therefore, it may be seen more in diabetic patients rather than inhibiting the development of diabetes. Because of the decrease in $\mathrm{T}$ cell and phagocytosis cell functions, it is important to evaluate patients with diabetes for $T$. gondii.

Malaria is a life-threatening disease caused by parasites that are transmitted to people through the bites of infected female Anopheles mosquitoes. It is also an important infection in human history [44]. According to data from the World Health Organization, approximately 300 million people catch malaria every year, and one million die of this infection [45].

Neutrophils, mononuclear phagocytes and NK cells play a role in innate immunity in malaria infections. Humoral immune response to infection occurs in people in endemic areas [46]. However, by stimulation of T cells, IgM and IgG and other globular proteins secreted by B lymphocytes do not have much effect on parasites and their developmental patterns [46]. It is possible that the Th- 1 response is involved in host immunity to malaria. Here, INF- $\gamma$ and TNF- $\alpha$ levels decreased. The increased risk of $\mathrm{P}$. falciparum infection in people with diabetes may be clinically important under various conditions. Semi-immunity controlling parasitemia is reported to be weakened by progressive diabetes. Despite the lack of semi-immunity in children in children with severe Type1 DM, it has been reported that there may be predisposition to catch malaria [47].

\subsection{Arthropods Infestations and Diabetes}

The relationship between diabetic patients and mites was investigated. The deterioration of the immune system was found to be an important factor in the occurrence of Norwegian scabies and may cause endocrine diseases such as diabetes [48].

Demodex folliculorum is one of the most common ectoparasites in humans and is reported to be more common 
in elderly and diabetic patients [49]. Akdeniz et al. [50] investigated the presence of $D$. folliculorum positivity in 54 type 2 DM patients, 28 male and 26 female, without any dermatological disease. In their study, DM patients were matched healthy people with of the terms of gender. Patients stopped using insulin 2 months ago and they did not use any medication. They found that the mean parasite density was higher in diabetic patients $(38.7 \%)$ than in healthy controls $(35.0 \%)$. In addition, parasites detected in diabetic patients were reported to be larger in size than detected in the control group. It was emphasized that immunosuppressive conditions may cause an increase in the density of $D$. folliculorum and the effect of hyperglycemia is very important and $D$. folliculorum may cause immune disorders.

Hemoglobin Alc (HbAlc) is a test used to monitor blood glucose levels in diabetic patients. HbA1c level determines the patient's blood glucose level in the last 3 months. It is an indicator of the development and progression of micro vascular complications of diabetes. In the present study, when the HbAlc level was examined, they found that the mean blood glucose level was very high and there was a positive correlation between the $D$. folliculorum $\mathrm{HbA} 1 \mathrm{c}$ levels [50].

\section{Conclusion}

Exposure to some parasites and microorganisms can prevent autoimmune diseases. In recent years, it has been observed that helminths can protect against many autoimmune diseases such as diabetes. However, protozoan infections and arthropod infestations may be more common in diabetic patients rather than preventing the development of diabetes. Increased autoimmune diseases such as diabetes in developed countries can be seen as a result of reduced exposure to certain infectious agents.

\section{References}

[1] American Diabetes Association. Diagnosis and classification of diabetes mellitus. Diabetes Care. 2009, 32 Suppl 1 (Suppl 1): $62-67$.

[2] Yilmaz H. Tip 1 Diabetes mellituslu Çocuklarda Gastroparezi, Glisemik Kontrol ve Helicobacter pylori Enfeksiyonu İlişkisi. Tipta Uzmanlık Tezi. 2005, Kayseri.

[3] Alemzadeh R, Wyatt DT, Diabetes mellitus in children. In: Behrman RF, Kliegman RM, Jenson HB (eds), Nelson Textbook of Pediatrics (17 th ed) W. B. Saunders Company, Philadelphia; 2000, 1947-1972.

[4] Saka HN. Diabetes mellitus. In: Günöz H, Öcal G, Yordam N (eds), Pediatrik Endokrinoloji (1 th ed) Pediatrik Endokrinoloji ve Oksoloji Derneği Yayınları, Ankara. 2003, 415-457.

[5] Saka HN. Diabetes mellitus. In: Neyzi O, Ertuğrul T (eds), Pediatri (3nd ed) Nobel Tip Kitabevi, İstanbul, 2002, 13061327.

[6] Bağrıaçık N. Tanı, komplikasyonlara yaklaşım, tedavi konsensus el kitabı. Novo Nordisk diabet servisi yayınları. 1997, İstanbul.

[7] King H, Aubert RE, Herman WH. Global Burden of Diabetes 1995-2025. Prevelance, numerical estimates and projections. Diabetes Care. 1998, 21: 1414-1421.

[8] Satman I, Yılmaz T, Şengul A. Population- based study of diabetes and risk characteristics in Turkey. Diabetes Care; 2002, 25: 1551- 1556.

[9] Zimmet P, Dowse G, Finch C, King H. The epidemiology and natural history of NIDDM -lessons from South Pasific. Diabetes Metabol Rev; 1990, 6: 91-124.

[10] Türken M. Tip 1 ve Tip 2 Diyabetes mellitus hastalıkların Patogenezinde D vitamini eksikliğinin Rolünün Araştırılması. Biyokimya Uzmanlık Tezi. 2011, Diyarbakır.

[11] Saltiel AR. New perspectives into the molecular pathogenesis and treatment of type 2 diabetes. Cell; 2001, 104: 517-29.

[12] Özcel MA. Genel Parazitoloji. Özcel MA, Özbel Y, Ak M, (eds). Özcel'in Tıbbi Parazit Hastalıkları. İzmir. 2007, 3-76.

[13] Özcel MA, İmmunoparazitolojiye Giriş. Özcel MA, İnci A, Turgay N, Köroğlu E (eds). Tibbi ve Veteriner İmmunoparazitoloji. İzmir. 2007, 5-18.

[14] Korkmaz İ, Eren ŞH, H, Beydilli İ. Diabet Hastalarında Toxoplazma gondii Antikorları Seroprevelansı. C. Ü. T1p Fakültesi Dergisi. 2006, 28 (1): 7-10.

[15] Jarvis D, Chinn S, Luczynska C, Burney P. The association of family size with atopy and atopic disease. Clin Exp Allergy. 1997, 27: 240-245.

[16] Strachan DP, Taylor EM, Carpenter RG. Family size, neonatal infection and hay fever in adolescence. Arch Dis Child; 1996, 74: 422-426.

[17] Von Mutius E, Martinez FD, Fritzsch C, Nicolai T, Reitmeir P, Thiemann HH. Skin test reactivity and number of siblings. BMJ, 1994, 308: 692-695.

[18] Zaccone P, Fehervari Z, Phillips JM, Dunne DW, Cooke A. Parasitic worms and inflammatory diseases. Parasite Immunol; 2006, 28 (10): 515-523.

[19] Gale EA. The rise of childhood type 1 diabetes in the 20th century. Diabetes; 2002, 51: 3353-3361.

[20] Pugliatti M, Sotgiu S, Rosati G. The worldwide prevalence of multiple sclerosis. Clin Neurol Neurosurg; 2002; 104: 182191.

[21] Liu Z, Liu Q, Bleich D, Salgame P, Gause WC. Regulation of type 1 diabetes, tuberculosis, and asthma by parasites. J Mol Med; 2010, 88 (1): 27-38.

[22] Sikirzhytski V, Sikirzhytskaya A, Lednev IK. Multidimensional Raman Spectroscopic Signatures as a Tool for Forensic Identification of Body Fluid Traces: A Review. Applied spectroscopy; 2011, Nov; 65 (11): 1223-32.

[23] Westa MJ and Wentb MJ. Detection of drugs of abuse by Raman spectroscopy. Drug Test. Analysis; 2011, 3: 532-538.

[24] Hanlon EB, Manoharan R, Koo T-W, Shafer KE, Motz JT, Fitzmaurice M, Kramer JR, Itzkan I, Dasari RR and Feld MS. Prospects for in vivo Raman spectroscopy. Phys. Med. Biol; 2000, 45, R1-R59. 
[25] Ellis DI. and Goodacre R. Metabolic fingerprinting in disease diagnosis: biomedical applications of infrared and Raman spectroscopy Analyst; 2006, 131: 875-885.

[26] Guevara E, Torres-Galván JC, Ramírez-Elías MG, LuevanoContreras C, González FJ. Use of Raman spectroscopy to screen diabetes mellitus with machine learning tools. Biomed Opt Express; 2018, 9 (10): 4998-5010.

[27] David P-G, Marzec KM, Hudson A, et al. Parasites under the Spotlight: Applications of Vibrational Spectroscopy to Malaria Research. Chem. Rev; 2018, 118: 5330-5358.

[28] Saunders KA, Raine T, Cooke A, Lawrence CE. Inhibition of autoimmune type 1 diabetes by gastrointestinal helminth infection. Infect Immun; 2007, 75 (1): 397-407.

[29] Faveuuw C, Mallevaey T, Paschinger K. Schistosome Nglycans containing core alpha 3 -fucose and core beta 2-xylose epitopes are strong inducers of $\mathrm{Th} 2$ responses in mice. Eur J Immunol; 2003, 33: 1271-1281.

[30] Raz I, Eldor R, Naparstek Y. Immune modulation for prevention of type 1 diabetes mellitus. Trends Biotechnol; 2005, 23 (3): 128-134.

[31] Mohebbatıkaljahı H. Tip 1 Diyabette Interlökin-10 Gen Ppromotör Bölgesi Polimorfizminin Çalışılması. Gazi Üniversitesi. Doktora tezi, 2007, Ankara.

[32] Liu Q, Sundar K, Mishra PK, Mousavi G, Liu Z, Gaydo A, Alem F, Lagunoff D, Bleich D, Gause WC. Helminth infection can reduce insulitis and type 1 diabetes through CD25- and IL10-independent mechanisms. Infect Immun; 2009, 77 (12): 5347-58.

[33] Toprak DE. İmmun ve Metabolik Regülasyon Arasındaki Karmaşık İlişki: Multiple Skleroz Patogenezinde Leptinin Rolü İstanbul Cerrahpaşa Öğrenci Bilimsel Dergisi 2010, 3 (4).

[34] Brode S, Raine T, Zaccone P, Cooke A. Cyclophosphamideinduced type-1 diabetes in the NOD mouse is associated with a reduction of $\mathrm{CD} 4+\mathrm{CD} 25+\mathrm{Foxp} 3+$ regulatory $\mathrm{T}$ cells. $\mathrm{J}$ Immunol; 2006, 177 (10): 6603-6612.

[35] Mallevaey T, Zanetta JP, Faveeuw C, Fontaine J, Maes E, Platt F, Capron M, de-Moraes ML, Trottein F. Activation of invariant NKT cells by the helminth parasite Schistosoma mansoni. J Immunol; 2006, 176 (4): 2476-2485.

[36] Mylaones KJ, Nair MG, Prieto-Lafuente L, Poope D, Allen JE. Alternatively activated macrophages elicited by helminth infections can be reprorammed to enable microbial killing. J Immunol; 2009, 182 (5): 3084-94.
[37] Joner G, Stene LC, Sovik O. Nationwide, prospective registration of type 1 diabetes in children aged $<15$ years in Norway 1989-98: no increase but significant regional variation in incidence. Diabetes Care; 2004, 27: 1618-1622.

[38] Özcel MA.. Schistosomiosis. Özcel MA, Özbel Y, Ak M, (eds). Özcel'in Tibbi Parazit Hastalıkları. İzmir. 2007, 475498.

[39] Roberts LS, Janovy J, Gerald D, Schmidt Larry S. Roberts. Foundations of Parasitology. Seventh edition, Mc Graw Hill Companies, Singapore. 2006.

[40] Zaccone P, Burton OT, Gibbs S, Miller N, Jones FM, Dunne DW, Cooke A. Immune modulation by Schistosoma mansoni antigens in NOD mice: effects on both innate and adaptive immune systems. J Biomed Biotechnol; 2010, 795210.

[41] Gökçe C, Yazar S, Bayram F, Gündoğan K, Tip 1 Diyabette Toxoplasma gondii Antikorları. Turkiye Klinikleri J Med. 2008, 28: (5).

[42] Hökelek M, Kahraman H, Uyar Y, Güdül Havuz S. Tip II Diabetes Mellitus'lu Hastalarda Toksoplazma Antikorlarının Seroprevalans1. Klinik Bilimler \& Doktor 2000, 6 (3): 302304.

[43] Gomez Marín JE, Pinon JM, Bonhomme A, Guenounou M. Does human toxoplasmosis involve an imbalance in T1/T2 cytokines? Med Hypotheses; 1997, 48 (2): 161-9.

[44] (https://www.who.int/news-room/fact-sheets/detail/malaria).

[45] World malaria report, 2008. World Health Organisation. Switzerland. WHO Press.

[46] Özcel MA. Sitma ve İmmunolojisi. Özcel MA, İnci A, Turgay N, Köroğlu E (eds). Tibbi ve Veteriner İmmunoparazitoloji. İzmir: 2007, 121-126.

[47] Danquah I, Bedu-Addo G, Mockenhaupt FP. Type 2 diabetes mellitus and increased risk for malaria infection. Emerg Infect Dis; 2010, 16 (10): 1601-4.

[48] Cestari TF, Martignago BF. Scabies, pediculosis, bedbugs, and stinkbugs: uncommon presentations. Clin Dermatol; 2005, 23 (6): 545-54.

[49] Clifford CW, Fulk GW. Association of diabetes, lash loss, and Staphylococcus aureus with infestation of eyelids by Demodex folliculorum (Acari: Demodicidae). J Med Entomol; 1990, 27 (4): 467-470.

[50] Akdeniz S, Bahceci M, Tuzcu AK, Harman M, Alp S, Bahceci S. Demodex folliculorum larger in diabetic patients? J Eur Acad Dermatol VenereolIs; 2002, 16 (5): 539-41. 